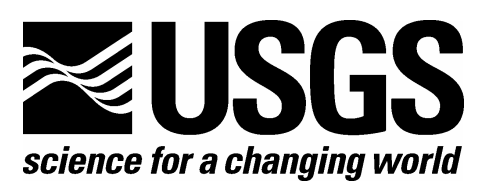

\title{
Integrating Stakeholders and Users into the Geography Discipline's Research Process
}

By Caroline M. Hermans and Richard Taketa

2006

Open File Report 2006-1344

U.S. Department of the Interior

U.S. Geological Survey 


\section{U.S. Department of the Interior \\ DIRK KEMPTHORNE, Secretary}

\section{U.S. Geological Survey \\ Mark D. Myers, Director}

\section{U.S. Geological Survey, Reston, Virginia 2006}

For product and ordering information:

World Wide Web: http://www.usgs.gov/pubprod

Telephone: 1-888-ASK-USGS

For more information on the USGS - the Federal source for science about the Earth, its natural and living resources, natural hazards, and the environment:

World Wide Web: http://www.usgs.gov

Telephone: 1-888-ASK-USGS

Suggested citation:

Hermans, C.M., and Taketa, Richard, 2006, Integrating Stakeholders and Users into the Geography Discipline's Research Process: U.S. Geological Survey Open File Report 2006-1344 [available on the World Wide Web at URL http://pubs.usgs.gov/of/2006/1344/ ].

Any use of trade, product, or firm names is for descriptive purposes only and does not imply endorsement by the U.S. Government.

Although this report is in the public domain, permission must be secured from the individual copyright owners to reproduce any copyrighted material contained within this report. 


\section{Contents}

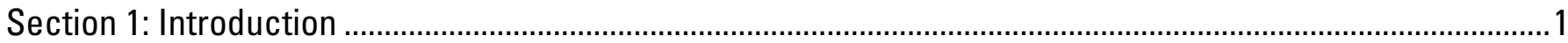

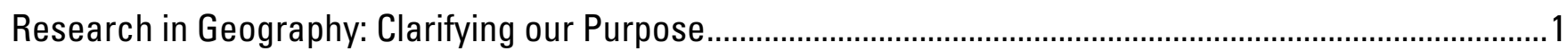

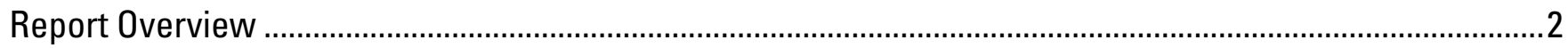

Section 2: Stakeholders and Geography's Research Process ........................................................................

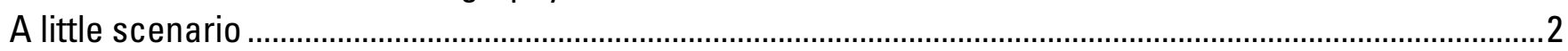

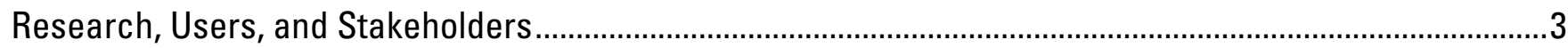

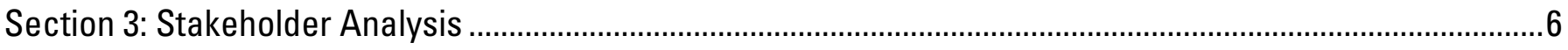

Identifying the Stakeholders................................................................................................................

Templates for organizing stakeholder information....................................................................................

1. Stakeholder Identification Checklist ....................................................................................................

2. Stakeholder Importance Matrix ..................................................................................................9

3. Stakeholder Influence and Importance Matrix ....................................................................................11

4. Matrix of Stakeholder Perspectives, Stakes/Interests, and Objectives ................................................12

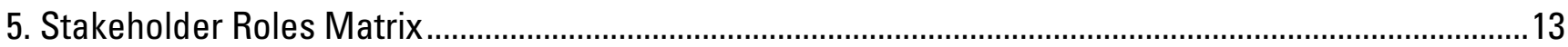

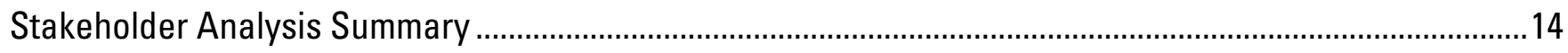

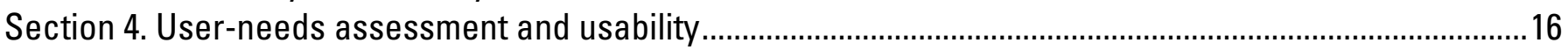

Tools for User-needs Assessment ....................................................................................................... 18

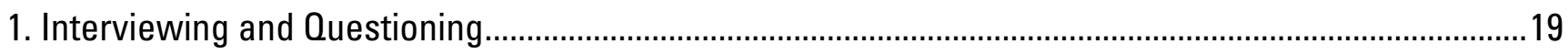

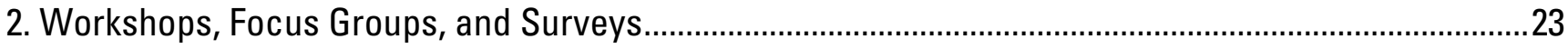

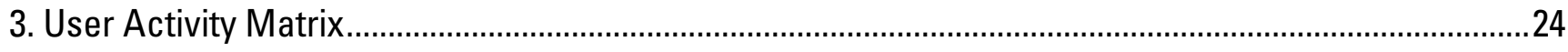

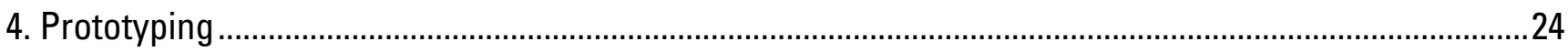

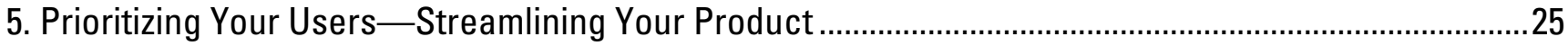

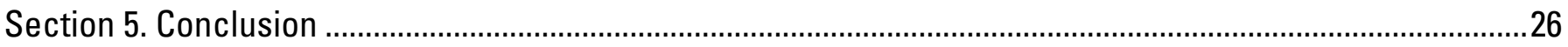

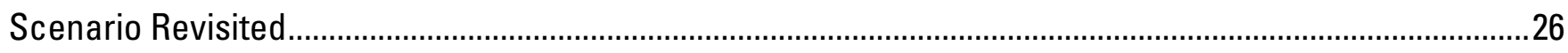

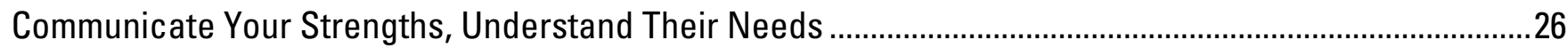

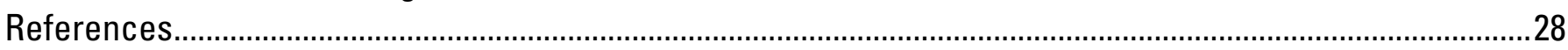

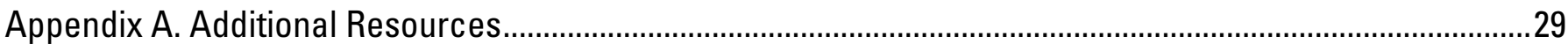

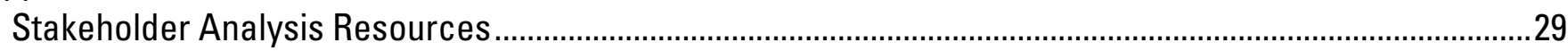

User-needs Resources .....................................................................................................................

Project Management Resources .......................................................................................................... 


\section{Figures}

Figure 1. Stakeholder relationships and connections-stakeholders represented on a hypothetical river management team and the roles they have on the team.

Figure 2. Stakeholder relationships and connections. This schematic shows the connections between water managers, users, and providers in an urban water district.

Figure 3. Influence and Importance Matrix. In this matrix, for example, towns have high influence and importance, river users, on the other hand, have little influence and are not central to the issue. 12

Figure 4. The ideal research product originates from collaboration between researchers and users...........17

Figure 5. User-needs assessment (UNA) within the stakeholder assessment process.

\section{Tables}

Table 1. Stakeholder-based research protocol...............................................................................................

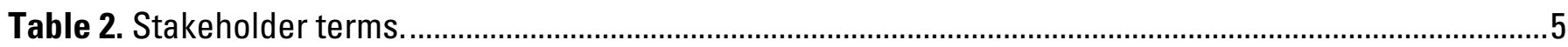

Table 3. Four "I's" of stakeholder involvement (adapted from Justice and Jamieson, 1999)..........................10

Table 4. An example of a Stakeholder Importance Matrix..........................................................................10

Table 5. Stakeholders perspectives, stakes and objectives in a hypothetical river management problem...13

Table 6. Sample Stakeholder Roles Matrix......................................................................................... 15

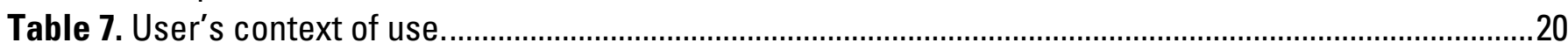

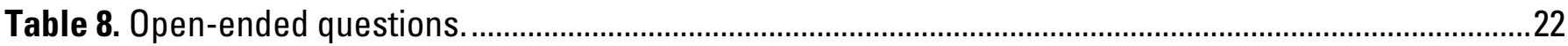




\section{Integrating Users and Stakeholders into the}

\section{Geography Discipline's Research Process}

By Caroline M. Hermans and Richard Taketa'

\section{Section 1: Introduction}

Applied collaborative research is about working with stakeholders, not on them.

\section{Research in Geography: Clarifying our Purpose}

Future research priorities of Geography emphasize the discipline's leadership role in the U.S. Geological Survey (USGS) in multidisciplinary and integrated research on human and environmental systems and how these systems are interrelated and respond to change (McMahon et al., 2005).

Geography's research priorities also emphasize providing science that is usable to society and creating decision support products applicable to given customer problems. To achieve these goals, we must understand the relationship between our research and our customer, and how to integrate the customer into the research process. ${ }^{2}$

This report details the elements of the research process that help achieve the degree of stakeholder involvement necessary to ensure a successful end-product. It offers suggestions that can help researchers better understand stakeholders and customers and involve them in the research process more effectively, while preserving the integrity of the science. Its aim is to help researchers understand the problems and challenges faced by our customers and communicate the ways in which Geography can help address their problems.

Adopting these guidelines can improve the efficiency of the research process and lead to higher quality output. We will be able to conduct better research because we will have an improved understanding of the research problem and the stakeholders involved.

\footnotetext{
${ }^{1}$ Caroline Hermans, U.S. Geological Survey, 345 Middlefield Road, MS 531, Menlo Park, CA 94025 , (650) 329-4225, chermans@usgs.gov; Richard Taketa, U.S. Geological Survey, MS 531, Menlo Park, CA 94025, (650) 329-4231.

${ }^{2}$ Note: USGS defines "customer" as the "users of our information" (USGS, 2000) and "research" implies applied collaborative research that involves a high degree of customer input.
} 


\section{Report Overview}

This report covers a broad range of topics, from identifying and communicating with stakeholders and users, to the use of language, to how to effectively present scientific information to the user. It does not offer a "one size fits all" method. Instead, perhaps only specific sections are suitable for a given project and customers, depending on project scope and needs. This report is based on the objectives of Geography's strategic plan (McMahon et al., 2005), U. S. Geological Survey's strategic plan (USGS, 2000), and Department of Interior's strategic plan (DOI, 2003).

Section 2 of these guidelines describes the purpose of the research process in Geography and the need for better user involvement in the process. Section 3 explains how to conduct a stakeholder analysis. Section 4 explains how to conduct a user-needs assessment.

\section{Section 2: Stakeholders and Geography's Research Process}

"Consultation, cooperation, and communication all in the service of conservation"

(DOI Strategic Plan, 2003)

\section{A little scenario}

Eric is developing a decision support product that will help the customer (Jane) make informed decisions about conserving wide buffers adjacent to a river. Eric and Jane are having a conversation early in the process to scope out the project requirements.

Eric: In your day-to-day work, what are your main concerns about the areas you are dealing with?

Jane: I am concerned about the effects of pollution on the river, as well as the effects of recreation and riparian development.

They agree on the development of a tool that will allow Jane to understand the effects on the river of these three variables. Eric and his research team develop a decision-support tool. Eric comes back 6 months later to present the work. After the presentation:

Jane: This is not helpful to me. I am not interested in pollution as it relates to the entire river; I am interested in how it relates to specific species and their microhabitats, namely river bottom dwellers. I didn't really want to look at the cumulative effects of pollution, development, and recreation; I wanted to look at these impacts on specific areas of the river. I am interested in the impact of development on specific riparian buffers-not on the river itself. Recreation is not as bad a problem as development and pollution, yet it seems this model considers it so.

Eric: But you said you were interested in the effects of pollution, recreation, and development on the river! So that is what we did. Did you change your mind? 
Jane: [growing irritated] I was talking about specific areas, not modeling the entire river - I am not even involved with what goes on miles downstream from here! So this is not useful at all!

Eric: [increasingly frustrated] But you said you were interested in the three impacts on the whole river.

Jane: Why would I say that if we already have a river-wide model that looks at the three factors as a whole, what am I going to do with 2 models that do the same thing? I want to know about the impacts on specific areas, that's what I said!

And on it goes.

The issue demonstrated by this example is the making of and acting on assumptions. Whatever you do, be careful about operating on assumptions. Through your conversations with the user, you want to either verify assumptions or throw them out. In reading this, the actions to take to ensure we do not end up here are obvious; it all comes down to communication. Unfortunately, there are no magic models that guarantee successful communication, but there are tools and skills that will help you in your communications with stakeholders and users.

So how do we ensure our research products are usable and useful to the user? First we must understand our users' needs by conducting a user-needs assessment. Secondly, we must communicate with the user during the project to ensure that their requirements are being met as the research product develops. Thirdly, as the research product is used, we must measure the usability of the product by looking at its effectiveness, efficiency, and the satisfaction of the user. The research products we design are used in complex social and institutional environments, and in order to ensure our research will be implemented, it is essential to understand these environments. As researchers in Geography involved with stakeholders, we are being asked to go beyond the science to design products that implement science in a useful way for the customer and other stakeholders.

\section{Research, Users, and Stakeholders}

The Department of Interior's Strategic Plan stresses the use of science and partnerships in order to serve communities by "advanc(ing) knowledge through scientific leadership and inform(ing) decisions through the applications of science" (DOI, 2003, p. 8). DOI's management approach suggests that "all of our activities will be customeroriented, designed to add value for citizens, partners, public-land users, and other agencies" (DOI, 2003, p. 21).

How can Geography Discipline's research process and products effectively reflect Geography, USGS, and DOI strategic objectives to serve communities, inform decisions, and orient research towards the customer? In traditional scientific research the initial starting point is the hypothesis to be tested, and customer involvement is not emphasized. A model is developed, data is collected and analyses are run. Under this framework, a customer is not necessarily identified to receive the research. Applied, collaborative geographic research has a different initial starting point. The focus is the customer and his problem. The research process begins with and is developed around the identified 
problem. Once the customer and problem are well defined, then the hypothesis, model development, data collection and analysis can happen.

A stakeholder-based research protocol can bring the customer into the research process, from the proposal phase through development and execution. The procedures in this protocol represent a shift in making collaborative and useful research an explicit part of a project. Table 1 details the steps in conducting stakeholder-based research.

Table 1. Stakeholder-based research protocol.

\begin{tabular}{|l|l|}
\hline Step 1 & $\begin{array}{l}\text { Departure point is the stakeholder problem or issue and the project proposal makes explicit } \\
\text { the needs and goals of the customer (problem), how the customer is integrated into the } \\
\text { research process (customer engagement), and how the research product meets the needs of } \\
\text { the customer (responsive products/services). The research hypothesis is developed around } \\
\text { the stakeholder problem. }\end{array}$ \\
\hline Step 2 & $\begin{array}{l}\text { Conduct stakeholder analysis. } \\
\text { Define stakeholders' roles, needs and priorities. } \\
\text { Evaluate potential of project success prior to embarking on project (based on stakeholder } \\
\text { analysis and consultation with customer). }\end{array}$ \\
\hline Step 3 & $\begin{array}{l}\text { Develop and define research question/hypothesis, conceptualize research product based on } \\
\text { problem formulation with customer input and assessment of their needs and priorities. }\end{array}$ \\
\hline Step 4 & $\begin{array}{l}\text { Product development: develop research product to target needs and priorities of the } \\
\text { customer. Continued customer interaction during research process to assure product meets } \\
\text { potentially changing customer needs. }\end{array}$ \\
\hline Step 5 & Application of product to customer problem. \\
\hline
\end{tabular}

*Note: For more information on aspects of project management, such as team management, project execution, time, quality and cost management, see the Resources section at the end.

The terms stakeholders, users, customer, and client, mean different things to different people. Below, these terms are defined as they are used in this paper. Each project is unique and, depending on project specifics, you may want to define these terms differently-just make sure that everyone on your research team is using these terms in the same way to avoid misunderstandings. Table 2 lists the most common stakeholder terms.

Stakeholders are broadly defined to include everyone with a vested interest or who is affected by your project. The term is also defined as "individuals or organizations who stand to gain or lose from the success or failure of a system" (Nuseibeh and Easterbrook, 2000); or “....any person, group, or institution that has an interest in (the project). This definition includes intended beneficiaries and intermediates, winners and losers, and those involved or excluded from the decision-making process" (EDIAS, 2001). The term "stakeholder" also includes customers, clients, users, and others involved in or affected by the project (table 2). 
Table 2. Stakeholder terms.

Stakeholder

Definition

\begin{tabular}{|c|c|}
\hline Sponsor & Approves project. May fund project. \\
\hline Customer, Client, User & The direct users of our research product or service. \\
\hline Primary Stakeholder & $\begin{array}{l}\text { Directly impacted by the project. } \\
\text { Directly involved in implementation. } \\
\text { Buy-in is needed for project to succeed. }\end{array}$ \\
\hline Secondary Stakeholder & Impacted by project, but in an indirect way. \\
\hline Experts & $\begin{array}{l}\text { Have critical information or data. } \\
\text { Have content knowledge specific aspects of the issue. } \\
\text { Develop data inputs, define political/social environment. } \\
\text { May be scientists, researchers in USGS, and from universities and local } \\
\text { organizations. }\end{array}$ \\
\hline Decision-maker & $\begin{array}{l}\text { May or may not be a stakeholder. May or may not be a user. } \\
\text { Buy-in from decision-maker(s) may be necessary for project to succeed. }\end{array}$ \\
\hline Audience & $\begin{array}{l}\text { Receivers of results of research from customer, they can be also be stakeholders } \\
\text { and/or decision-makers and/or secondary users. }\end{array}$ \\
\hline Primary user & $\begin{array}{l}\text { The customer (although in some cases, the customer might be different from the } \\
\text { primary user). } \\
\text { May or may not be a decision-maker. If not decision-maker, will probably have } \\
\text { role influencing decision-maker. }\end{array}$ \\
\hline Secondary user & Also uses research product, but is not main user. \\
\hline Big picture user & $\begin{array}{l}\text { Concerned with output/results of research product and its impact on targeted } \\
\text { stakeholders. }\end{array}$ \\
\hline Technical user & $\begin{array}{l}\text { Concerned with usability, interface, and output capabilities of product from } \\
\text { technical standpoint. }\end{array}$ \\
\hline Data providers & Similar to experts, provide data inputs to research. \\
\hline
\end{tabular}

(Adapted from Justice and Jamieson, 1999.)

Analyzing stakeholder and user-needs are two different processes. A stakeholder analysis accomplishes multiple goals. It identifies the primary and secondary users of the research product. It identifies other parties who have a stake or can influence the project directly or indirectly. It also characterizes the political, socioeconomic, and cultural environment of the stakeholders and the degree of conflict or collaboration that might exist. Finally, it characterizes the relationships between the parties and how they interact.

Stakeholder analysis differs from user-needs assessment by focusing on identifying the project's key players, assessing their interests, and the ways in which those interests affect project risk and viability (Allen and Kilvington, 2001). "A stakeholder analysis aims to identify the characteristics of key stakeholders, assess the manner in which they might affect or be affected by the project, understand relationships between stakeholders (including potential conflicts of interest and expectations), and 
capacity to participate" (Gavin and Pinder, 2001, p. 2). In contrast, user-needs assessment focuses on the specific project features necessary to meet the requirements of those users.

Stakeholder analysis "contributes to project design by identifying the goals and roles of different groups, and by helping to formulate appropriate forms of engagement with these groups" (Allen and Kilvington, 2001).

Why is stakeholder analysis important? Going straight to the user of your product and not spending time and other resources on analyzing stakeholders is tempting. As one consultant puts it, "user-centered design professionals pay special emphasis to one type of stakeholder - the users of the system-arguing that user experience needs to be carefully crafted to satisfy user-needs. While understanding user-needs and goals is certainly necessary, it is often not sufficient for producing a successful design. "Design needs to incorporate the goals and perspective of other stakeholders in order to get their buy-in and be considered a success..." (Boutelle, 2004).

Although conducting a stakeholder analysis sounds straightforward and relatively easy, the breakdown of stakeholders' roles can be complicated and messy. Often, stakeholders play multiple roles in a problem, with complex relationships among different players. The primary users are not always obvious, and without a stakeholder analysis the project may be well underway before it becomes apparent that the wrong users have been targeted.

Stakeholder analysis helps the researcher understand the political, economic, institutional, and social climate of the user, because this can have a tremendous influence on the impact of a project. For example, a project may be conducted very differently if it is understood that the users do not have the decision-making power necessary to implement the project with their stakeholders. The research being developed might be used for different purposes in different situations, and in some situations the chances of the research being useful might be greater than in others. Understanding stakeholders through an analysis would have told you who the true decision-makers are. Your stakeholder analysis may also tell you that they are not ready to make use of your science. In this case, you will need to redirect your project to ensure that the research product is usable.

A stakeholder analysis is especially important if the customer is planning to use your product in consultation with their stakeholders (secondary users). Do not assume they have conducted a stakeholder analysis. Instead, make sure you understand who their stakeholders and users are and how your product is to be used. For example, the partner organization says that their stakeholders are interested in the effect of a natural hazard in a given area. If this is not a result of a stakeholder assessment, but an assumption, then time and resources could be wasted if the secondary user is actually interested in a different hazard in a different area. Assuming you know who all the players are and what they need from you is all too easy, but you will be operating blindly unless you conduct the appropriate analyses.

\section{Section 3: Stakeholder Analysis}

The scope of the stakeholder analysis is different for each project. Sorting out all the different players will be more difficult for some projects than others, and there is no 
one "correct" way to conduct an analysis. Basically, your analysis will consist of talking to people involved in the project and determining their interests, goals, and relationships to others involved. The way in which you communicate with stakeholders as a USGS researcher is so important that this guide contains a section on communication (see Section 4).

One of the simplest ways to keep track of your stakeholders is to put them in a matrix and categorize them according to a set of criteria. You can categorize your stakeholders in a number of ways; the templates on the following pages offer some examples. The stakeholder analysis should be based on information from the stakeholders and not your assumptions or the opinions of other experts outside the scope of the problem.

\section{Identifying the Stakeholders}

Identifying the stakeholders is probably the most difficult task of the stakeholder analysis. There is no easy way to know who all the stakeholders are, especially in complex, large-scale environmental problems. The first step is to talk to the stakeholders you know are involved. Through the course of your conversations with them, other interested parties will be identified. You will want to talk to these parties as well. You will want to ask each contact to identify other parties involved in this issue. As you talk to contacts, your understanding of the stakeholders involved in the issue and their roles and importance will mature. There will come a point that you will have a fairly complete initial picture of relevant stakeholders and their role in the issue (although it will probably change as the project progresses). The following templates can help clarify the roles, relationships, priorities, and importance of the stakeholders identified.

\section{Templates for organizing stakeholder information}

You can organize information collected during a stakeholder analysis in a variety of ways. Several tools are described below, but this is by no means an exhaustive list. For more stakeholder tools, please see the Additional Resources section at the end of this report. The tools used will depend on the preferences of your research team for organizing information. Although these tools might seem simple and perhaps busy work, they can be very valuable in fostering a common understanding amongst research team members and promoting a deeper understanding of the parties involved.

\section{Stakeholder Identification Checklist}

One of the simplest techniques is to create a simple stakeholder checklist or matrix to help you define the different stakeholders involved in your project. The steps involved in creating a stakeholder identification matrix are:

(1) List known and potential stakeholders

(2) Differentiate and group stakeholders

- Primary and secondary stakeholders

- Others 
(3) Brainstorm to determine who are the key stakeholders and ask known stakeholders to identify other potential stakeholders.

- Define role

- Assign importance

- List potential interests

(adapted from Groot, 2001; Overseas Development Agency, 1994)

A schematic is another simple way to define the stakeholders, as shown in figure 2. It is a simple diagram that charts out the relationships and connections among stakeholders. Using schematics can promote understanding among project researchers and facilitate communication about the project.

Figure 1. Stakeholder relationships and connections-stakeholders represented on a hypothetical river management team and the roles they have on the team.

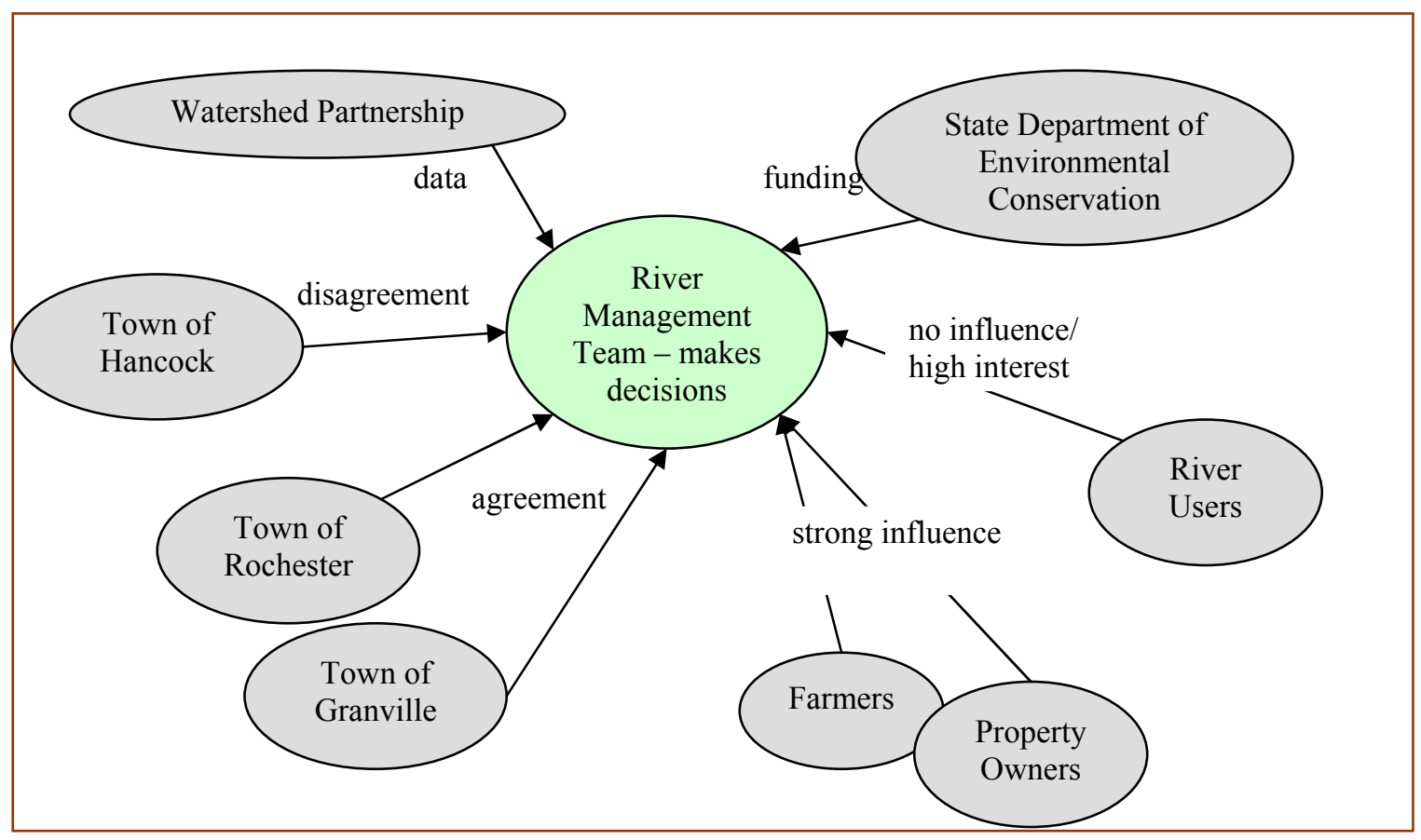


Figure 2. Stakeholder relationships and connections. This schematic shows the connections between water managers, users, and providers in an urban water district.

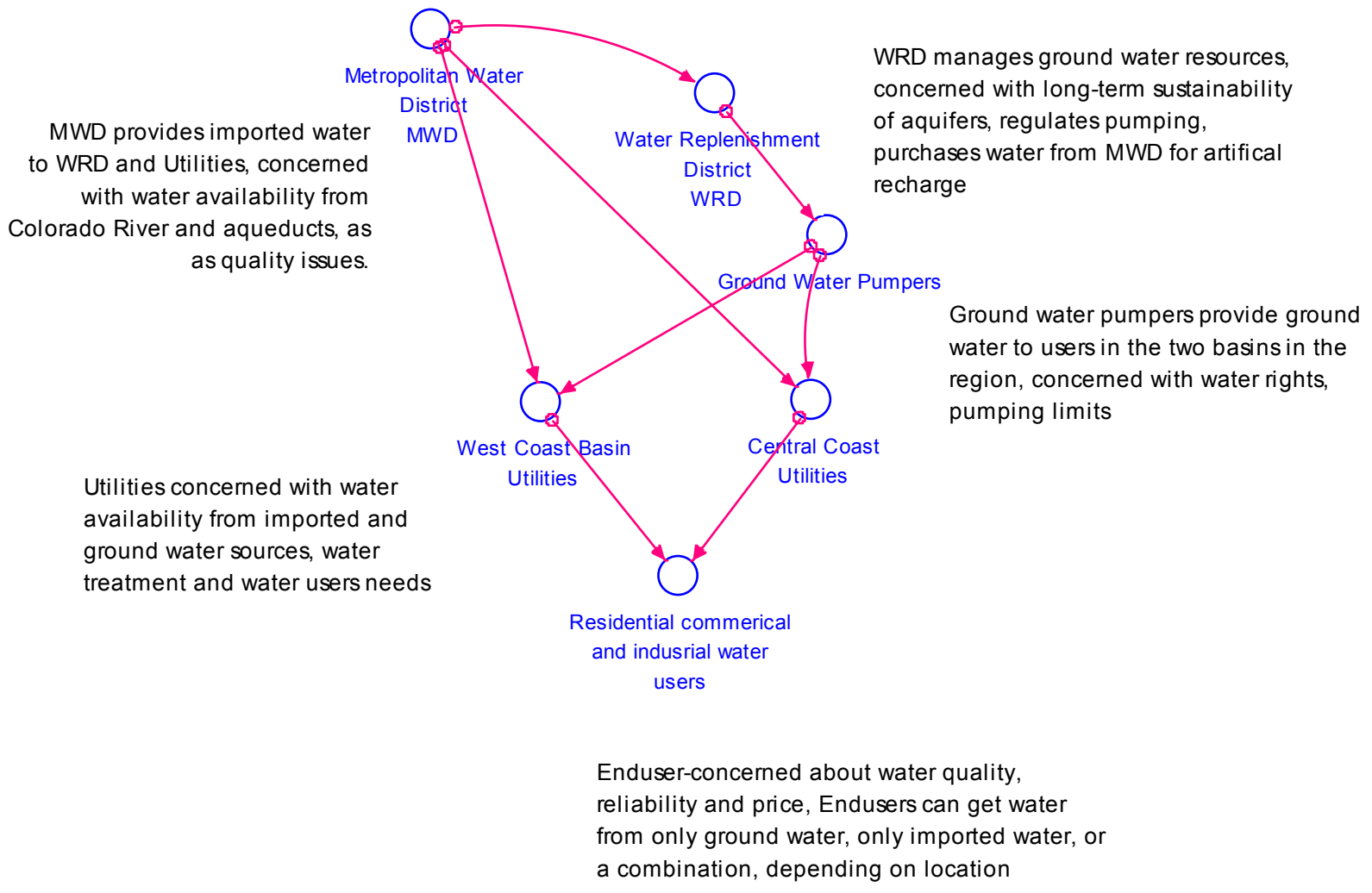

\section{Stakeholder Importance Matrix}

Another, more detailed way to organize stakeholders is by their involvement in the project through a Stakeholder Importance Matrix. Justice and Jamieson (1999) group stakeholders in the "four I's" of involvement, as summarized in table 3: 
Table 3. Four "I's" of stakeholder involvement (adapted from Justice and Jamieson, 1999).

\begin{tabular}{|c|l|l|}
\hline Involvement & \multicolumn{1}{|c|}{ Definition } & \multicolumn{1}{|c|}{ Example } \\
\hline Influence & Those with influence to block decisions & $\begin{array}{l}\text { Primary stakeholders } \\
\text { Decision makers } \\
\text { Client }\end{array}$ \\
\hline Interest & Those with demonstrated interests in the work of the group & $\begin{array}{l}\text { Primary stakeholders } \\
\text { Decision makers } \\
\text { Client }\end{array}$ \\
\hline Impacted & Those who will be affected by decisions & Stakeholders \\
\hline Intelligence & $\begin{array}{l}\text { Those who possess data needed to contribute to an intelligent } \\
\text { database }\end{array}$ & Expert partners \\
\hline
\end{tabular}

This basic importance matrix can be expanded to include the role of each stakeholder and any significant relationships among stakeholders. This includes both their informal and indirect relationships. Explicitly defining stakeholder relationships and degree of importance can be important in politically charged situations.

Table 4 offers an example of a stakeholder importance matrix used to rate the importance of each party/participant based on the Four-I's (on a scale of 1-5, $1=$ low, $5=$ high). The stakeholders with the highest totals are the most central to the project. Note that the attributes are equally weighted in this case. In reality, attributes deemed more important could be weighted to allow for prioritization of the attributes.

Table 4. An example of a Stakeholder Importance Matrix.

\begin{tabular}{|c|c|c|c|c|c|c|c|}
\hline Stakeholder & Stakeholder Role & 遶 & 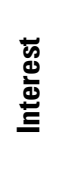 & 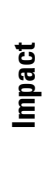 & 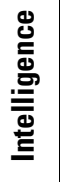 & ฮ్ّ & Significant Relationship \\
\hline $\begin{array}{l}\text { Resource } \\
\text { Managers }\end{array}$ & $\begin{array}{l}\text { Customer/ } \\
\text { User }\end{array}$ & 2 & 5 & 5 & 5 & 17 & $\begin{array}{l}\text { Communicate directly to } \\
\text { development board }\end{array}$ \\
\hline Developers & Primary Stakeholder & 4 & 1 & 5 & 2 & 12 & $\begin{array}{l}\text { Vocal and at odds with resource } \\
\text { managers }\end{array}$ \\
\hline $\begin{array}{l}\text { Community } \\
\text { Members }\end{array}$ & Primary Stakeholder & 3 & 4 & 5 & 2 & 14 & $\begin{array}{l}\text { Some are developers, influence } \\
\text { decisions through communication } \\
\text { with county development board }\end{array}$ \\
\hline $\begin{array}{l}\text { County } \\
\text { Development } \\
\text { Board }\end{array}$ & $\begin{array}{l}\text { Secondary } \\
\text { stakeholder and } \\
\text { major decision } \\
\text { maker }\end{array}$ & 5 & 5 & 4 & 4 & 18 & Advises water management board \\
\hline $\begin{array}{l}\text { Department of } \\
\text { Interior }\end{array}$ & Sponsoring agency & 3 & 5 & 2 & 1 & 11 & Employ park managers \\
\hline
\end{tabular}




\section{Stakeholder Influence and Importance Matrix}

Groot's (2001) Stakeholder Importance and Influence Matrix is similar to the Stakeholder Importance Matrix (above). Stakeholders are plotted based on their importance and influence, as in figure 2 above. This displays stakeholder influence and importance in a more graphical form.

The influence of a stakeholder is evaluated by the following determinants (these determinants can be modified based on the needs of the project):

- Administrative or legal hierarchy

- Authority of leadership

- Control of strategic resources for the project

- Possession of specialist knowledge

- Negotiation position

The importance of a stakeholder in the process refers to "the importance given to satisfy stakeholders' needs and interests." Two questions can be asked to decide how important a stakeholder is (1) "Which stakeholders do we regard as priority, in terms of meeting their needs, interests, and expectations?" and (2) "Which stakeholders' interests converge most closely with the sponsor's objectives?" (Groot, 2001). Note that the Influence and Importance Matrix, as with any of these templates, can be completed not only by the researchers but by the stakeholders as well. Having the stakeholders complete these templates will give the researcher a lot of information about individual stakeholder's perspective on their role/influence/importance in respect to the roles/influence/importance of other stakeholders. 
Figure 3. Influence and Importance Matrix. In this matrix, for example, towns have high influence and importance, river users, on the other hand, have little influence and are not central to the issue.
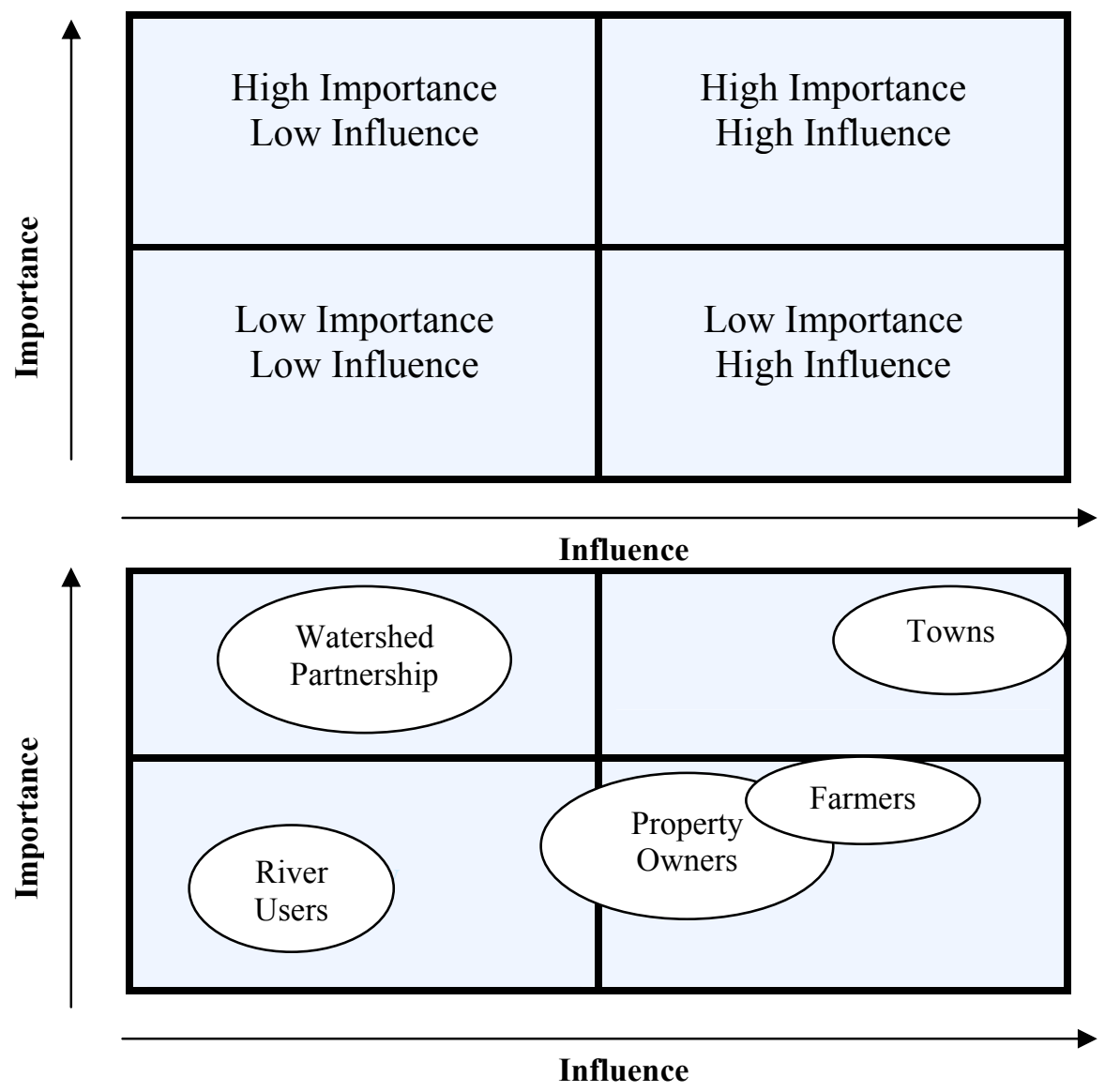

\section{Matrix of Stakeholder Perspectives, Stakes/Interests, and Objectives}

Another way to analyze stakeholders is to understand the perspectives stakeholders hold about the problem as well as the stake they have in the problem. This extends analyzing relationships to include their perceptions of the problem and their desired objectives. If applicable, conflicting and shared perspectives among stakeholders should be analyzed.

Perspectives and objectives can be organized together through the development of an objectives-perspectives matrix. This will provide researchers with a clearer idea of where stakeholders agree and disagree, as well as what their respective goals are. In table 5 below, the matrix combines perspectives, objectives, and what stakeholders have at stake for a hypothetical river management issue. 
Table 5. Stakeholders perspectives, stakes and objectives in a hypothetical river management problem.

\begin{tabular}{|c|c|c|c|c|c|}
\hline Stakeholder & $\begin{array}{l}\text { Perspective on } \\
\text { reasons for } \\
\text { problem }\end{array}$ & $\begin{array}{l}\text { Perspectives } \\
\text { on solutions for } \\
\text { problem }\end{array}$ & Stake & Objectives & $\begin{array}{l}\text { Conflict / } \\
\text { opposing } \\
\text { perspective }\end{array}$ \\
\hline $\begin{array}{l}\text { Riparian } \\
\text { landowner }\end{array}$ & $\begin{array}{l}\text { Nature causes } \\
\text { problems (for } \\
\text { example, } \\
\text { flooding) }\end{array}$ & $\begin{array}{l}\text { State needs to } \\
\text { ensure private } \\
\text { property is } \\
\text { protected }\end{array}$ & $\begin{array}{l}\text { Own riparian } \\
\text { land }\end{array}$ & $\begin{array}{l}\text { Keep land } \\
\text { productive } \\
\text { with no } \\
\text { erosion, no } \\
\text { loss of land } \\
\text { to the river }\end{array}$ & $\begin{array}{l}\text { With } \\
\text { environmentalists }\end{array}$ \\
\hline $\begin{array}{l}\text { Department of } \\
\text { Environmental } \\
\text { Conservation }\end{array}$ & $\begin{array}{l}\text { Channelization } \\
\text { of river by } \\
\text { state, poor } \\
\text { understanding } \\
\text { of river system } \\
\text { dynamics }\end{array}$ & $\begin{array}{l}\text { Education of } \\
\text { river users, land } \\
\text { owners - allow } \\
\text { river to return } \\
\text { to natural state; } \\
\text { establish } \\
\text { buffers, } \\
\text { meanders }\end{array}$ & $\begin{array}{l}\text { Pay for river } \\
\text { management } \\
\text { (flood costs, } \\
\text { erosion/ } \\
\text { sedimentation } \\
\text { control) }\end{array}$ & $\begin{array}{l}\text { Decrease } \\
\text { flood } \\
\text { mitigation } \\
\text { costs, long } \\
\text { term river } \\
\text { system } \\
\text { health }\end{array}$ & $\begin{array}{l}\text { With local } \\
\text { governments, } \\
\text { riparian } \\
\text { stakeholders }\end{array}$ \\
\hline $\begin{array}{l}\text { Watershed } \\
\text { Partnership }\end{array}$ & Channelization & $\begin{array}{l}\text { Education, } \\
\text { allow river to } \\
\text { return to natural } \\
\text { state }\end{array}$ & $\begin{array}{l}\text { Concern for } \\
\text { river health, } \\
\text { private } \\
\text { economic } \\
\text { interests, } \\
\text { community } \\
\text { river needs }\end{array}$ & $\begin{array}{l}\text { Balance } \\
\text { river and } \\
\text { community } \\
\text { needs }\end{array}$ & $\begin{array}{l}\text { Tries to represent } \\
\text { all interests }\end{array}$ \\
\hline Local towns & $\begin{array}{l}\text { State needs to } \\
\text { riprap and } \\
\text { remove gravel } \\
\text { more } \\
\text { extensively }\end{array}$ & $\begin{array}{l}\text { State needs to } \\
\text { riprap and } \\
\text { remove gravel; } \\
\text { continue } \\
\text { channelization }\end{array}$ & $\begin{array}{l}\text { Flooding } \\
\text { problems }\end{array}$ & $\begin{array}{l}\text { Increase } \\
\text { developable } \\
\text { land }\end{array}$ & $\begin{array}{l}\text { State/Watershed } \\
\text { Partnership }\end{array}$ \\
\hline
\end{tabular}

(Adapted from Groot, 2001)

\section{Stakeholder Roles Matrix}

Finally, a stakeholder roles matrix is an effective way of clarifying stakeholder relationships. It requires more effort than the techniques described above, but it "assists understanding of who does what in relation to the 'system of interest' so that gaps and overlaps in roles can be identified and acted upon. Looking at stakeholder roles assists in identifying weaknesses due to duplication of effort, competition, or just poor task performance" (Groot, 2001). This can also be completed for research roles as a part of the project work plan if there are many parties involved to identify gaps and overlaps in research roles.

The steps in developing a stakeholder role matrix are (1) identify relevant individual stakeholders (see Defining Stakeholder section above) and define the roles and 
tasks involved and (2) Assess roles by scoring each stakeholder's role in terms of function and importance. The matrix can take different forms, depending on the project needs. An example of a roles matrix for stakeholders is presented in table 6 .

\section{Stakeholder Analysis Summary}

The level of detail needed for a stakeholder analysis will vary with the situation. In some cases, you will have an established set of stakeholders, and the process involves simply verifying that the situation has not changed. In others, you may have a complex set of primary, secondary, and indirect stakeholders, and the analysis will involve a detailed investigation of their interests and relationships. The templates provided here are tools you can adapt to your specific research project. All of these templates can be customized to suit the needs of the project and your research team. 
Table 6. Sample Stakeholder Roles Matrix.

\begin{tabular}{|c|c|c|c|c|c|c|c|c|c|}
\hline \multicolumn{10}{|c|}{ Stakeholder Roles in Project Refuge } \\
\hline Name & Organization & Title & Role & Specific contribution & Data/ & $\begin{array}{c}\text { Primary } \\
\text { Stakeholder }\end{array}$ & $\begin{array}{l}\text { Product } \\
\text { User }\end{array}$ & Client & $\begin{array}{l}\text { Decision } \\
\text { Maker }\end{array}$ \\
\hline R. Jones & State Government & & Sponsor & Funding/guidance & & & & +++ & \\
\hline P. Higgins & State Government & & $\begin{array}{l}\text { Main point of } \\
\text { contact }\end{array}$ & Liaison, knows all the players & +++ & & ++ & +++ & \\
\hline $\begin{array}{l}\text { Drs. Jones } \\
\text { and } \\
\text { Hayward }\end{array}$ & $\begin{array}{l}\text { State Wildlife } \\
\text { Refuge }\end{array}$ & Managers & USER & $\begin{array}{l}\text { Will use our research in } \\
\text { decision-making process } \\
\text { involving refuge boundaries and } \\
\text { extent }\end{array}$ & & +++ & +++ & & +++ \\
\hline M. Ivy & $\begin{array}{l}\text { Neighborhood } \\
\text { Association, } 50 \\
\text { members }\end{array}$ & Head & $\begin{array}{l}\text { Primary } \\
\text { Stakeholder }\end{array}$ & $\begin{array}{l}\text { Communicates concerns of } \\
\text { neighboring community } \\
\text { regarding refuge impacts }\end{array}$ & & ++ & & & \\
\hline N. Nage & Local government & $\begin{array}{l}\text { Town } \\
\text { Planner }\end{array}$ & Stakeholder & $\begin{array}{l}\text { Development planning of town, } \\
\text { helps look at possible impacts } \\
\text { on refuge }\end{array}$ & & ++ & & & + \\
\hline $\begin{array}{l}\text { Drs. } \\
\text { Mitchell, } \\
\text { Olhan }\end{array}$ & USGS & Biologists & Provide data & Refuge data & +++ & & & & \\
\hline H. Abe & $\begin{array}{l}\text { Local } \\
\text { environmental } \\
\text { group }\end{array}$ & Head & $\begin{array}{l}\text { Provide input, } \\
\text { stakeholder }\end{array}$ & $\begin{array}{l}\text { Concerned about health of } \\
\text { refuge }\end{array}$ & + & + & & & \\
\hline \multicolumn{10}{|c|}{ Critical/fully involved } \\
\hline \multicolumn{10}{|c|}{ Important } \\
\hline+ & \multicolumn{9}{|c|}{ Secondary/partially involved } \\
\hline$?$ & \multicolumn{9}{|c|}{ Unknown } \\
\hline$?+++$ & \multicolumn{9}{|c|}{ Potentially critical, no communication yet } \\
\hline
\end{tabular}




\section{Section 4. User-needs assessment and usability}

User-needs assessment (UNA) is the process of understanding the requirements, objectives, and priorities of the user to help ensure that a research product addresses the needs of the users. It is not a one time analysis, but continues over the life of the project. Tied in with UNA is usability, defined by the International Standards Organization (ISO) standards as, "the degree to which a product can be used by specific users to reach specific goals with efficiency, effectiveness, and satisfaction in a given use context" (Alva, 2003). Bevan (1995) states that usability is synonymous with 'quality of use' and that it is difficult to operationalize usability as an objective of a product. Usability implies that the purpose of a product is to help the user achieve particular goals, therefore, to measure usability, we need to understand these goals through a UNA.

UNA is an exchange of information intended to find the common interests of the user and the researcher. Users bring their understanding of the Earth science problem to the discussion. We, as researchers, help the user understand our research capabilities. All too often, users may not understand and be able to articulate their own needs. So, in addition to explaining our research capabilities, we must assist the user in specifying the problem and understanding their priorities. If done well, this exchange between researcher and user leads to a clear identification of user's needs that the researcher can address (fig. 4). 
Figure 4. The ideal research product originates from collaboration between researchers and users.

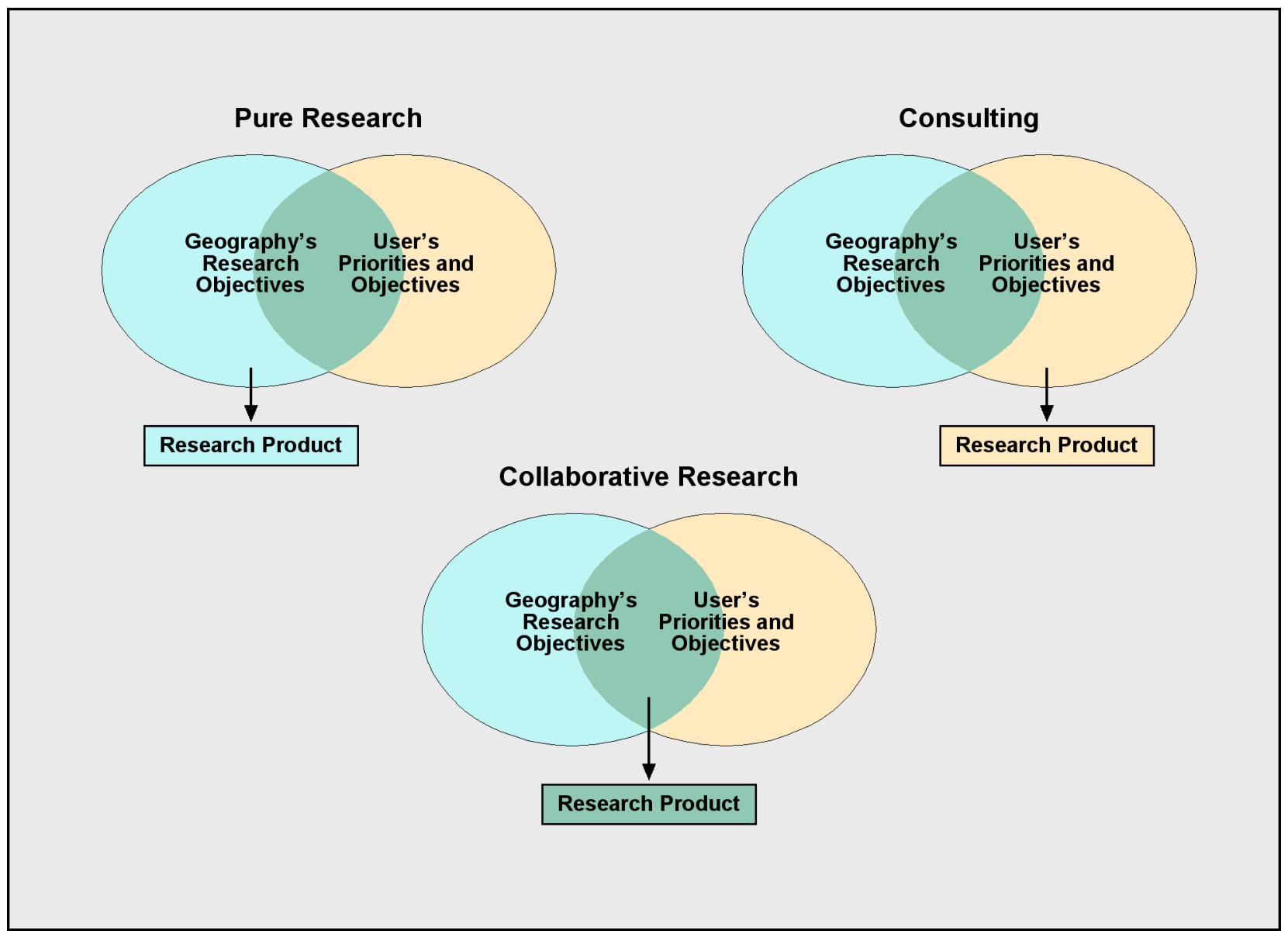

Bevan (1995) sees two approaches to usability, bottom up, where usability is synonymous with ease of use and a broader, top down approach, where usability is "the ability to use a product for its intended purpose." The broader approach captures the possibility that a research product can be "usable but not useful," or useful but not usable, and seeks to capture user perceptions. This is subjective usability and it is where the user and usability interact. A correctly executed user-needs assessment captures these user perceptions and dictates the kind of usability required.

The usability consultancy, Information and Design (ID) states the following in regard to the importance of conducting a user-needs assessment and addressing usability concerns:

"Designers, who don't understand their users, frequently develop products that are difficult to use and understand, do not meet real-world requirements, or provide irrelevant

functionality...The world of users is messy. Once we start to ask questions like, 'How does our user make decisions currently?' or, 'Why doesn't our user consider x, y, or z?' we enter a murky world with multiple answers that are not easy to obtain...Often, developers simply extrapolate from their own experience. Given the huge gap in technical expertise between developers and users, the resulting product is likely to be less than ideal. This is a pity, because getting good quality, useful information about users is not terribly difficult. (Developing) in the 
dark rarely allows developers to meet the needs of users of a given application. To do that, you have to get to know your users" (Gaffney, 2004).

When we enter the realm of user-needs assessment, we begin addressing the relationship, not among different stakeholders, but between the customer and the actual product. The stakeholder analysis informs the user-needs assessment in that product development (user-needs) takes into consideration the specifics of the given decision problem and the people involved (stakeholder analysis). The user-needs assessment focuses on developing a hypothesis-driven research product that conforms to the priorities and objectives of the customer. Given the technological nature of our research products, we rely heavily on software development and Web-design fields for examples on how to conduct a user-needs assessment.

Foremost, our needs assessment relies on the relationship we develop with our user. There is no canned way to develop user relationships. Communication skills, such as effective listening and asking the right questions are the most important ingredients of a successful user-researcher relationship. The section on how to ask questions, below, may be helpful for those that do not know how to start talking to your users or are uncomfortable with user interactions.

You want to talk to users about their needs and objectives. In most cases this should be done in the proposal stage, as early as possible in the research process. Ideally, you will meet users in person, via site visits. The benefits of visiting the user onsite, including reduced costs down the line, more than compensates for this initial cost (Houser, 2005). You can often coordinate the UNA with the stakeholder analysis.

The needs of different users (primary, secondary, and indirect) will differ. The stakeholder analysis will identify these different levels of users, and the needs of each group will be evaluated during the needs assessment. Users' needs and political and economic climates, as well as who the stakeholders are might change during the life of the project and you will benefit from awareness of these changes and adapting the research product if necessary.

\section{Tools for User-needs Assessment}

UNA tools offer ways to think about the needs of the users and break down the components of the needs of the user. Remember that user-needs assessment is a qualitative, not quantitative exercise. Many of the tools below may also be applicable to conducting a stakeholder analysis. Figure 5 illustrates the interrelated steps necessary to understanding your clients. The broad stakeholder analysis comes first; this step identifies the key stakeholders and is described in the first part of this report. Then comes the user-needs assessment, embedded within the stakeholder analysis, consisting of (1) understanding your client's context of use and (2) understanding their specific requirements of your research product. 
Figure 5. User-needs assessment (UNA) within the stakeholder assessment process.

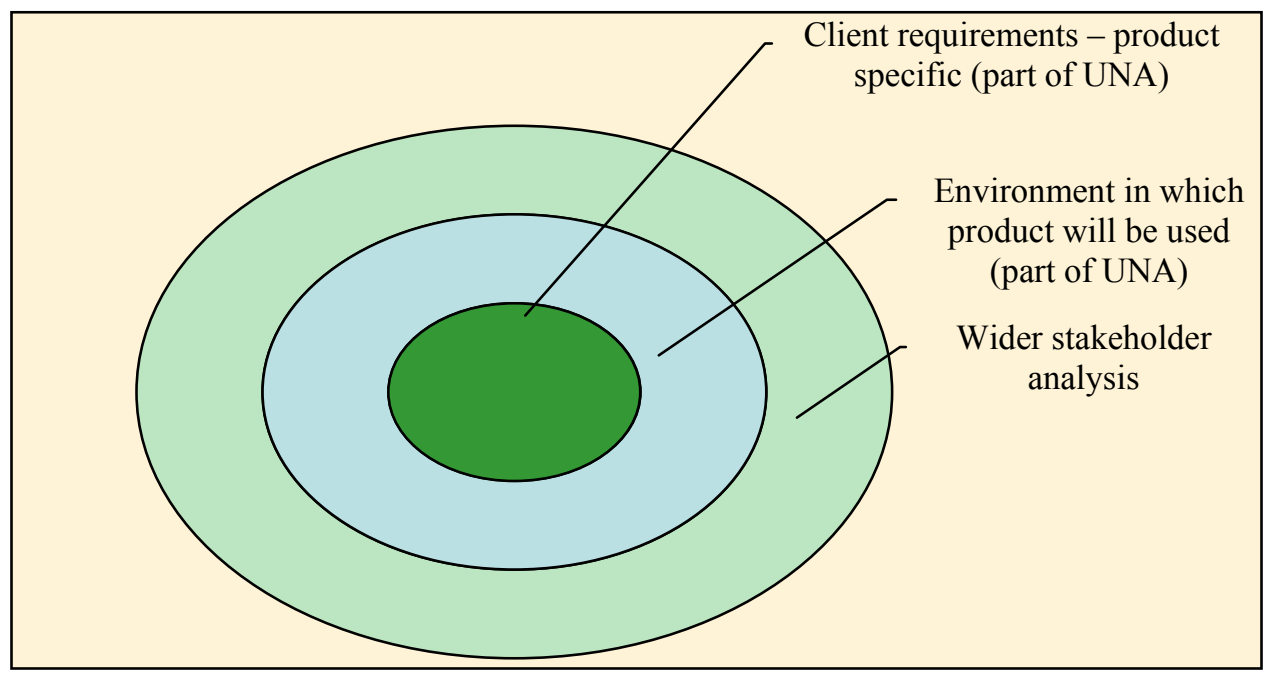

These "tools" come in the form of ways to think about the needs of your users, breaking down the components of the tasks of the user, questions to ask about the needs of the user, and other issues.

\section{Interviewing and Questioning}

A. Context of Use. What is the world within which the user operates?

The researcher must understand the environment within which the client will use the product to develop a research product that is useful to the client. This environment is the client's "context of use." If you can understand the different contexts presented in table 7, you are well on the way to understanding the user's context of use. 
Table 7. User's context of use.

1. Primary (immediate) application areas of the research product:

- user expectations

- benefits of product to user

2. Future potential application areas of research product

3. Perceived/anticipated task breakdown, dependencies and output:

- tasks of the user that pertain to the research product

- data inputs needed by the user

- outputs required by user

4. Intended audience and/or secondary user that will use the research product:

- capabilities of audience

- extent of their knowledge pertaining to the research area

5. Interests/priorities of the user that might conflict with the project

(Adapted from MUSiC Breakdown of Context, in Bevan, 1995; Overseas Development Agency, 1995)

Understanding the user's context of use means communicating with them extensively; there are no shortcuts to reach this understanding. Remember, stakeholders and users are not simple objects of study. They will only be understood through your communication with them.

\section{A. Semistructured interview}

The semistructured interview is one of a variety of techniques you can use to understand your user's perspective. Structured processes are efficient but require training to perform. Conversely, unstructured conversations without any predetermined questions or agenda can be interesting, but inefficient. Semistructured interviews fall in between, structuring conversations within a topic boundary, but without having detailed questions formulated ahead of time (Food and Agriculture Organization (FAO), 1990).

The semistructured interview is a directed conversation covering more general topics/questions, moving to more specific issues as the interview progresses. Several questions may be predetermined to begin and lead the conversation. Relevant topics and issues are defined early on and more specific questions are based on these topics and issues. Questions become more specific as the conversation progresses, and these questions are created during the interview. The advantages of the semistructured interview are that it is less intrusive than a formal interview, encourages two-way conversation, and provides "not just answers, but the reasons for the answers" (FAO, 1990).

You will probably have a great many questions to ask and the challenge will be to avoid overburdening the user at your first meeting. Instead, group and prioritize all your questions under topics. Pick specific topics for the first meeting. Remember, you will be having many more conversations with the user.

The process for conducting semistructured interviews is as follows (adapted from FAO, 1990; Houser, 2005):

(1) Brainstorm potential topics and initial questions before interview. 
(2) Use broad, open-ended questions. Give the user time to respond and use your voice and body language to encourage them to talk. Remain flexible and follow the most promising trail.

(3) During the interview, allow users to tell their story. Really listen to the user, record only brief notes, and elaborate on notes after the interview.

(4) Remember, the first meeting(s) is not the time for you to remedy the situation. Do not offer advice or focus the interview on your research. This is a key point that researchers often forget! Instead, encourage users to think aloud and allow them to do most the talking.

(5) Clarify-summarize what the user says to clarify your and their understanding.

(6) Listen for nonverbal clues-subtle criticisms, suggestions, and innuendos.

(7) Analyze results of interview and summarize your understanding. Separate facts and problems from your own opinions, ideas, or solutions.

(8) Talk to interviewee to clarify if necessary.

Pitfalls to avoid when using semistructured interviews are asking leading questions, getting too much information, straying off track, and, in the case of group interviews, having users interrupt or not speak up (FAO, 1990). Table 8 contains a list of open-ended questions that will help you get started in your interviews. 
Table 8. Open-ended questions.

- How do you perform task $\mathrm{x}$ (that is, evaluate which areas to mitigate)?

$\diamond$ Gets at task-subtask structure, can then ask about each subtask. This is very important in understanding what components the user may want in your model.

- Why do you perform task $x$ ?

- Under what conditions do you perform task $\mathrm{x}$ ?

- What do you do before you perform....?

- What information do you need to...?

- Whom do you need to communicate with ...?

- What do you use to ...?

- What happens after you ....?

- What is the result or consequence of ....?

- What is the result or consequence of NOT...?

- Please show me how you currently do task x.

- Why do it this way rather than some other way?

$\diamond$ Attempts to get user to explain method so you can assess importance of the particular way of doing task.

- What are the current problems with task $\mathrm{x}$, currently?

- What else should I have asked you?

- Encourage DIGRESSIONS, ask for ELABORATIONS

- Ask for examples

$\checkmark$ What is an example of the impact of $x$ ?

- What are some typical problems you encounter?

- If you could change one thing about how you currently do it, what would it be?

Here are some more specific questions you might want to have answered:

- What are the specific inputs to your decision making?

- What inputs are critical?

- What inputs are missing?

- What are your current outputs?

- What is missing?

- What potential additional outputs would make your task easier?

- What happens to the output?

- What is this task dependent on?

- What is the availability of information?

(Adapted from Foley, 2005)

C. Communicating the skills of your research team and research abilities

When you have had your initial interaction(s) with users and better understand their needs and priorities, you will talk to them about how your research project and goals can address their needs. Here are a few basic points to remember:

- This takes time! Plan for several conversations to clarify the needs of the user and to communicate your research abilities. 
- Do not tell the user how they can benefit from your research; instead ask them how they see your research fitting their needs. Your research project will automatically be sold when you listen to the user and use your project to address his needs. Once you have explained your project, ask the users to think of all the ways it might go right or wrong.

- Ask them to list what is most important/salient to them in terms of issues the research product could address and have them prioritize this list (Boutelle, 2004).

- Ask them to talk about the ways they have addressed their issues/challenges in the past and what worked or did not work.

- Ask the user to talk about his ideal world in terms of the issues the project is going to address. You want to help the user really think about how his problem and your potential solutions can work together.

Note: Just because a user says something in a certain way, it doesn't mean it is that way. You may misunderstand what the user is saying; the user may be saying one thing, but meaning something else. Make sure you AND the user achieve a clear, common understanding. This may take time.

As you and the user talk, not only are you clarifying your ideas, but the user is also clarifying his ideas. You should allow the user to formulate his ideas and requirements, knowing that where you end up might not be where you started. The user may not like your initial ideas, and you need to be prepared for this. Use this as a way to get at what the user really wants by asking, for example, "If you do not want to look at soil samples, what would you like to consider? Can you list the different indicators you do think are important?" Strive to understand the fit between the user's concerns and your research ideas.

"Issues provide opportunities if you can address them in your design, but they become pitfalls if you're unaware of them, and fail to allow for their effects on users." (Gaffney, 2004)

\section{Workshops, Focus Groups, and Surveys}

Conducting workshops or focus groups for potential users is a good way to gather information as to their needs, priorities, and objectives. For example, in a project involving ground water and hazards in southern California, a workshop was held early in the project to better understand how ground-water managers and communities in two ground-water basins were preparing for potential natural hazard events. The workshop elicited much information on a wide range of topics in a short amount of time from many people and was a valuable initial step to better understanding what stakeholders needed in terms of modeling the impacts of natural hazards on ground water. The workshop also served as an opportunity to identify potential long-term users of the research model. A second workshop is planned to present a prototype for further evaluation.

Workshops take time to prepare. Skilled facilitators must be used and the workshop should be highly interactive. Plan on taking up to three to four months to plan your workshop. Logistical details include where to hold it, who to invite, workshop structure and agenda, food, transportation, invitations, and follow-up calls. Workshop content development is time-consuming, and it is important to involve the facilitator and all researchers on the project in designing and testing the workshop content. You should identify the major objective(s) of the workshop and plan workshop sessions around these objectives. Using a skilled facilitator is key to developing a strong workshop.

Surveys are another way to find out the needs and priorities of a wide range of potential users. For more information and government guidelines on conducting surveys, see 
http://www.whitehouse.gov/omb/inforeg/pmc_survey_guidance_2006.pdf. Federal guidelines require that surveys be approved by the Office of Management and Budget. For planning purposes, plan for a 6-month survey approval process. This is in addition to survey development time, pretesting, and peer review.

\section{User Activity Matrix}

Users may not be involved in all stages of your research. Organizing their input in an activity matrix, based on the stages of the research process, will help identify when and how users will be involved (table 9). Depending on the project, users will be involved more in some stages than others.

Table 9. User Activity Matrix.

\begin{tabular}{|l|l|l|l|l|}
\hline & \multicolumn{1}{|c|}{ Planning } & \multicolumn{1}{c|}{ Analysis } & \multicolumn{1}{c|}{ Design } & \multicolumn{1}{c|}{ Evaluation } \\
\hline Primary User & $\begin{array}{l}\text { Involve user in } \\
\text { planning process, } \\
\text { visit user on-site }\end{array}$ & $\begin{array}{l}\text { Consult with user on } \\
\text { monthly basis, } \\
\text { depending on data } \\
\text { needs }\end{array}$ & $\begin{array}{l}\text { Present user with } \\
\text { prototype for input } \\
\text { after initial modeling } \\
\text { phase }\end{array}$ & $\begin{array}{l}\text { User formally or } \\
\text { informally evaluates } \\
\text { research product for } \\
\text { future use, gives } \\
\text { input for } \\
\text { modifications }\end{array}$ \\
\hline Secondary User & Not involved & Not involved & $\begin{array}{l}\text { After input from } \\
\text { primary user, } \\
\text { prototype is } \\
\text { introduced to } \\
\text { secondary users for } \\
\text { input }\end{array}$ & $\begin{array}{l}\text { May or may not be } \\
\text { consulted to evaluate } \\
\text { final product }\end{array}$ \\
\hline
\end{tabular}

For example, some researchers involve users in the modeling process on a regular basis. The users are part of the modeling team and have input, along with the researchers, on how the model is developed. In other projects, users participate in weekly conference calls to provide input. In some projects, users may be involved in initial project development, but not in any of the analysis or design. Consult with your users early in the project to define the level of involvement that is appropriate to both you and the user.

\section{Prototyping}

A prototype is a sufficiently complete representation of the research product (and the process into which the product will fit) that can serve as the basis for discussion with a user. It identifies the inputs (available data, control parameters, and others), the outputs (maps, graphs, reports, data types - numeric, categorical, textual - and the precision and accuracy of the results), and the processes that transform the data.

A prototype is like an outline of the research. It need not be fully functional; some of the steps might be simulated or "canned." In fact, the prototype could be developed and presented entirely on paper, like a storyboard. The idea behind building a prototype is to help both you and the user visualize the research product and the user's process. 
Prototypes fall into several categories. Horizontal prototypes broadly cover the process steps, but without details on individual steps. Vertical prototypes focus on specific process steps, capturing the details of those steps. Revolutionary prototypes are rough representations intended to be discarded, whereas evolutionary prototypes are more complete representations intended to be developed into the final product. Any prototype may be a combination of these types. For example, the prototype might be primarily horizontal, with some vertical elements. This might occur when the research project will focus primarily on one process step, such as understanding the impact of an environmental policy. The horizontal process steps will provide the context within which the research will take place, showing how the research results will connect to the rest of the user's process. The vertical portion of the prototype will give details on how the impacts will be determined. You may select any combination of these approaches to fit your research situation.

Treat prototyping as a trial-and-error process. Early prototypes may miss the target, so don't invest too much effort in details. However, each successive prototype should be closer to the target. This suggests that your early prototypes should be revolutionary-throwaway-rather than evolutionary, and more likely to be horizontal than vertical. The prototypes will be developed more fully as the research progresses, until you have a fairly complete picture of the steps in the process, and how your research will fit into that process. Use the prototyping process to help solidify your thinking, and as a way to communicate your thinking to your user.

\section{Prioritizing Your Users-Streamlining Your Product}

You may have identified several potential users with various needs who can benefit from your research product. Unless you have unlimited funding and time, you should target your product to specific user groups and applications. You will, generally, want to develop research products that are adaptable to different situations, transparent, and can accept additional capabilities easily. Rating potential applications of your product according to several criteria can help you prioritize your user applications (table 10). Rating or ranking potential applications of your research product can help you clarify and anticipate the direction of your research development.

Table 10. Rating potential applications on a scale of 1 to 5 , with 5 being most difficult.

\begin{tabular}{|l|c|c|c|c|c|}
\hline \multicolumn{1}{|c|}{$\begin{array}{c}\text { Potential Application of } \\
\text { product }\end{array}$} & $\begin{array}{c}\text { Development } \\
\text { ease }\end{array}$ & $\begin{array}{c}\text { Multiple } \\
\text { conflicting } \\
\text { uses }\end{array}$ & $\begin{array}{c}\text { Adaptions to } \\
\text { current } \\
\text { design }\end{array}$ & $\begin{array}{c}\text { Data needs/ } \\
\text { availability }\end{array}$ & $\begin{array}{c}\text { Future } \\
\text { funding } \\
\text { Potential }\end{array}$ \\
\hline $\begin{array}{l}\text { Evaluate hazards for } \\
\text { individual neighborhoods }\end{array}$ & 5 & 5 & 5 & 5 & 5 \\
\hline $\begin{array}{l}\text { Evaluate hazards at } \\
\text { community level }\end{array}$ & 4 & 4 & 5 & 4 & 5 \\
\hline $\begin{array}{l}\text { Evaluate hazards at } \\
\text { regional level }\end{array}$ & 2 & 2 & 3 & 4 & 3 \\
\hline
\end{tabular}




\section{Section 5. Conclusion}

\section{Scenario Revisited}

If we replay our original scenario, incorporating some of the techniques from stakeholder analysis, it might look something like this:

Eric is developing a research product that will help Jane make decisions about conserving areas of land adjacent to a National Park. They are having a conversation early in the process to scope out project requirements.

Eric: In your day-to-day work, what are your main concerns about the areas you are dealing with?

Jane: I am concerned about the effect of pollution on the river, as well as the effects of tourism and development.

Eric: So your main concerns center around the effects of pollution and development and recreation on the river?

Jane: No. I am talking about three separate issues. I mean that I want to focus on certain species and how they are affected by pollution. That really doesn't have to do with recreation.

Eric: Really, how come?

Jane: Well, recreation is an issue, but a secondary issue, the impact is not as bad as for development and pollution.

Eric: Can you talk some more about the species that are impacted by pollution?

Jane: Well...

Later...

Eric: You know, earlier you talked about development. Could you expand on that, what in particular interests you about this issue?

Jane: I am talking about fragile riparian areas and how development impacts them.

Eric: [probing further] What aspects of development concern you most?

And so on it goes.

\section{Communicate Your Strengths, Understand Their Needs}

Each project should (1) complete a stakeholder analysis in the early stages of project development, (2) ensure that researchers communicate with users throughout the process, and (3) a complete a user-needs assessment in conjunction with the stakeholder analysis. This report is an initial effort to describe how these tasks can be accomplished.

The two main messages of this report are (1) we are challenged as researchers to understand the needs of our clients, and (2) we may be even more challenged to effectively communicate to customers and stakeholders our research products and how they can fulfill their needs. This is an 
integral part of the relationship — asking the right questions of our customers but also telling them about our strengths.

Often the customer may not understand what they need, and often the customer does not understand what we can do. Entire conversations can take place between the researcher and customer where they think they are talking about the same thing, but are discussing two different things entirely. They may share the same vocabulary but give different meanings to the same words. Think about the words "risk" and "vulnerability"-chances are they do not mean the same thing to the scientist and the user.

Both the scientist and customer may be seeing the issue from only their individual perspectives. The customer may not understand the science behind their problem adequately, and the researcher may not understand the preferences of the customer. Also, the customer may have difficulty in communicating to the researcher what they need - they may not have the language and the knowledge base. Often it seems like scientists and laypeople speak two different languages, and the key is to get them on the same page so they can understand each other. Part of our challenge is in applying our research products to help stakeholders understand why and how our research can help them. The tools described in this report and the sources listed in the appendix can facilitate this communicative process.

In the end, this is about communication, not tools or methods. Subscribe to the following:

- Put aside your "researcher" side and talk to your stakeholders as people (not as experimental objects).

- Make the effort to understand their point of view.

- Use language common to your stakeholders and customers.

- Listen, listen, listen.

- Clarify, clarify, clarify.

- Don't assume-check out your assumptions! And then check again.

- Communicate your strengths and know that it takes time.

Good luck and have fun!!! 


\section{References}

Allen, W., and Kilvington, M., 2001, Stakeholder analysis:

[http://www.landcareresearch.co.nz/research/social/stakeholder.asp. (accessed November 2005)]

Alva, M. E., Martinez Prieto, A.B., Cueva Lovelle, J.M., Sagastegui, T.H., and Lopez, B., 2003, Comparison of methods and existing tools for the measurement of usability in the web: In Web Engineering, v. 2722/2003: Heidelberg, Springer Berlin, p. 386-389.

Bevan, N., 1995, Measuring usability as quality of use: Software Quality Journal, v.4, p. 115-150.

Boutelle, J.,2004, Understanding organizational stakeholders for design success. [http://www.boxesandarrows.com/archives/understanding_organizational_stakeholders_for _design_success.php. (accessed November 2005)].

Enterprise Development Impact Assessment Information Service (EDIAS), 2001, Toolbox:

Stakeholder Analysis. [http://www.enterprise-

impact.org.uk/informationresources/toolbox/stakeholderanalysis.shtml. (accessed September 2005)]

Food and Agricultural Organization (FAO), 1990, The community's toolbox: the idea, methods, and tools for participatory assessment, monitoring and evaluation in community forestry. Community Forestry Field Manual 2. Rome, Food and Agriculture Organization of the United Nations.

Foley, J., 2005, Requirements gathering - know the user, Web lecture, Georgia Institute of Technology: Human Centered Computing.

Gaffney, G.,2004, Contextual enquiry - a primer. [http://www.sitepoint.com/article/contextualenquiry-primer. (accessed November 2005)].

Gavin, T., and Pinder, C., 2001, Impact assessment and stakeholder analysis. [http://www.enterpriseimpact.org.uk/informationresources/toolbox/stakeholderanalysis.shtml. (accessed December 2005)]

Groot, A. M., 2001, Stakeholder matrices: guidelines. [http://www.icraedu.org/objects/anglolearn/ACFegJqyr.pdf. (accessed October 2005)]

Houser, R., 2005, Asking the right questions during a site visit interview: Society for Technical Communication International Conference. Seattle, WA.

Justice, T., and Jamieson, D.W., 1999, The facilitator's fieldbook: New York, AMACOM.

McMahon, G., Benjamin, S.P., Clarke, K., Findley, J.E., Fisher, R.N., Graf, W.L., Gundersen, L.C., Jones. J.W., Loveland, T.R., Roth K.S., Usery, E.L., and Wood, N.J., 2005, Geography for a changing world: A science strategy for the geographic research of the U.S. Geological Survey, 2005-2015: U.S. Geological Survey, Circular 1281.

Nuseibeh, B., and Easterbrook, S., 2000, Requirements engineering: a roadmap: In A.C.W. Finkelstein (ed), Future of Software Engineering: New York, ICSE, p.147-160.

Overseas Development Administration (ODA), 1994, Guidance note on how to do stakeholder analysis of AID projects and programmes. [http://www.euforic.org/gb/stake1.htm. (accessed November 2005)]

U.S. Department of the Interior, 2003, U.S. Department of the Interior: Strategic Plan FY 20032008: U.S. Department of the Interior.

U.S. Geological Survey, 2000, Strategic Plan, 2000-2005: U.S. Geological Survey. 


\section{Appendix A. Additional Resources}

\section{Some Great Web Sites and Books on Stakeholder Analysis and User-Needs Assessment}

\section{Stakeholder Analysis Resources}

Often, development organizations' Web Sites have a lot of information on how to conduct projects with similar issues to Geography's and can be a valuable resource.

- New Zealand's, Manaaki Whenua Landcare Research is involved in sustainable development and has a brief overview on the stakeholder process with definitions, reasons for conducting a stakeholder analysis, and how to conduct one (http://www.landcareresearch.co.nz/ research/social/stakeholder.asp).

- International Centre for development oriented Research in Agriculture-ICRA has a development approach they call Agricultural Research for Development (ARD). ICRA founded in 1981 by European members of the Consultative Group on International Agricultural Research (CGIAR), a consortium of donor agencies. ICRA has a very well thought-out 'learning resource' on stakeholder analysis (http://www.icraedu.org/page.cfm?pageid=anglolearnstakeholders). For the complete ARD procedure, see http://www.icra-edu.org/objects/anglo/ARD-complete1.pdf. (This document also provides invaluable information on organizing your research team and project plan.)

For:

- Key stakeholder concepts: http://www.icra-edu.org/objects/anglolearn/StakeholdersKey_Concepts.pdf

○ Stakeholder approaches: http://www.icra-edu.org/objects/anglolearn/StakeholdersApproaches 1.pdf

- Stakeholder matrices: http://www.icraedu.org/objects/anglolearn/ACFegJqyr.pdf

- Information on topics from interviews and surveys to cost benefit analysis to systems thinking to visualization see http://www.icra-edu.org/page.cfm?pageid=anglores

- United Kingdom Department of International Development's Overseas Development Administration (ODA) - for guidance on how to do stakeholder analysis from the (http://www.euforic.org/gb/stake1.htm)

- MSP Resource Portal: Building Your Capacity to Facilitate Multi-Stakeholder Processes and Social Learning (http://www.iac.wur.nl/msp/). The MSP Resource Portal has practical information on how to facilitate participatory learning processes with various stakeholders. It provides theoretical foundations, methods and tools to create learning processes, facilitation tips, examples, literature and links. For the section on stakeholder analysis and interviews, focus groups, brainstorming see http://www.iac.wur.nl/msp/index.php?Stakeholder_analysis. 
- Australian Government's Overseas Aid Program - a very nice website on project management that contains a section on stakeholder analysis (http://www.ausaid.gov.au/ausguide/).

- Enterprise Development Impact Assessment Information Service-EDIAIS was established in 2001. The focus may be on rural development, but the resources on this site are highly applicable to our research process. There is extensive information on the following:

○ Stakeholder analysis: http://www.enterpriseimpact.org.uk/informationresources/toolbox/stakeholderanalysis.shtml

○ Impact assessment: http://www.enterprise-impact.org.uk/overview/index.shtml

$\circ$ Project management, quantitative and qualitative methods in analysis, and information collection (see the toolbox resource section at http://www.enterpriseimpact.org.uk/informationresources/toolbox.shtml).

- World Bank Group-Social Analysis Sourcebook has relatively short notes on strategic approaches to stakeholder analysis and social assessments in projects. (http://www.worldbank.org/socialanalysissourcebook/5elements3.htm).

- Food and Agriculture Organization-FAO's web site is a good place to get information about all the different tools you can use in stakeholder analysis and user needs. (http://www.fao.org/docrep/x5307e/x5307e00.HTM)

\section{User-needs Resources}

- Boxes and Arrows is a peer-written journal about usability. For information on user-needs and stakeholder analysis, and why we need both see http://www.boxesandarrows.com/archives/understanding_organizational_stakeholders_for_desi gn_success.php. For case studies on usability see http://www.boxesandarrows.com/story/index/date/1. There are case studies from egreetings, Yahoo!, MSWeb, PeopleSoft, Razorfish, Blogger, and others. Some studies are more applicable to Geography's research process than others, but there are fascinating studies about others' experiences in usability.

- University of Maryland's Usability Testing site-Although, primarily for software engineering and web design the web site has good links to other usability sites (http://www.otal.umd.edu/guse/testing.html)

- For a great case study on usability involving LOTUS for windows see (http://sigchi.org/sigchi/chi96/proceedings/desbrief/Ashlund/sla1txt.htm)

- Georgia Tech's Human Centered Computing Education website has terrific sources on user-needs: http://hcc.cc.gatech.edu/index.php.

- Institute of Museum and Library Services completed a UNA titled-Assessment of EndUser-needs in IMLS-Funded Digitization Projects. This document contains great information on a UNA and the findings are very relevant to our research (pgs. 2-6 contain a good summary) (http://www.imls.gov/pdf/userneedsassessment.pdf).

- University of California, Berkeley's Electronic Environmental Library Project is a user-needs assessment and evaluation that reports the preliminary results. There is a nice bibliography at the end of the report. (http://csdl.tamu.edu/DL95/papers/vanhouse/vanhouse.html). 
- USOR, A collection of User Oriented Methods: This site has a great collection of user methods - constructive interaction to thinking aloud. It also has methods grouped by activities, user involvement, and goals. (http://www.nada.kth.se/cid/usor/)

- Nielsen, Jakob, 1993, Usability Engineering: Boston, AP Professional, Boston, MA.

- Beyer, H. and Holtzblatt, K, 1998, Contextual Design: Defining Customer-Centered Systems: San Francisco, Morgan Kaufmann. Written for software developers, this book contains information on how to relate effectively to your stakeholders, customers. See Chapter 3: Principles of Contextual Inquiry - especially the information on the Master-Apprentice Model and Partnership.

\section{Project Management Resources}

- GIO Project Management Office has a project management methodology that is very good. Their website is http://internal.usgs.gov/gio/pmo.html, and the link to their guide is http://internal.usgs.gov/gio/pmo/pmmgiofinal.pdf

- Project Management Institute, 2004, A Guide to the Project Management Body of Knowledge: Newtown Square, Pennsylvania, Project Management Institute. Comprehensive guide on project management (basis for GIO PM methodology). See Chapter 3 for the PM processes, Chapter 5 for project scope issues and breaking down the project into executable parts.

- Berkun, Scott, 2005, The Art of Project Management: Sebastopol, California, O'Reilly Media. Topics include: where ideas come from, Hitting moving targets. A fun book that confronts project management pitfalls head on. Berkun comes from a software development background and a lot of the information in this book is applicable to the research process we go through in the Geography Discipline. 